\title{
Characterization of Dutch dairy farms using sensor systems for cow management
}

\author{
W. Steeneveld ${ }^{* 1}$ and H. Hogeveen ${ }^{*} \dagger$ \\ ${ }^{*}$ Chair group Business Economics, Wageningen University, Hollandseweg 1, $6706 \mathrm{KN}$ Wageningen, the Netherlands \\ †Department of Farm Animal Health, Faculty of Veterinary Medicine, Utrecht University, Yalelaan 7, 3584 CL Utrecht, the Netherlands
}

\begin{abstract}
To improve cow management in large dairy herds, sensors have been developed that can measure physiological, behavioral, and production indicators on individual cows. Recently, the number of dairy farms using sensor systems has increased. It is not known, however, to what extent sensor systems are used on dairy farms, and the reasons why farmers invest or not in sensor systems are unclear. The first objective of this study was to give an overview of the sensor systems currently used in the Netherlands. The second objective was to investigate the reasons for investing or not investing in sensor systems. The third objective was to characterize farms with and without sensor systems. A survey was developed to investigate first, the reasons for investing or not in sensor systems and, then, how the sensor systems are used in daily cow management. The survey was sent to 1,672 Dutch dairy farmers. The final data set consisted of 512 dairy farms (response rate of 30.6\%); 202 farms indicated that they had sensor systems and 310 farms indicated that they did not have sensor systems. A wide variety of sensor systems was used on Dutch dairy farms; those for mastitis detection and estrus detection were the most-used sensor systems. The use of sensor systems was different for farms using an automatic milking system (AMS) and a conventional milking system (CMS). Reasons for investing were different for different sensor systems. For sensor systems attached to the AMS, the farmers made no conscious decision to invest: they answered that the sensors were standard in the AMS or were bought for reduced cost with the AMS. The main reasons for investing in estrus detection sensor systems were improving detection rates, gaining insights into the fertility level of the herd, improving profitability of the farm, and reducing labor. Main reasons for not investing in sensor systems were economically related. It was very difficult to characterize farms with and without sen-
\end{abstract}

Received July 10, 2014.

Accepted October 8, 2014.

${ }^{1}$ Corresponding author: wilma.steeneveld@wur.nl sor systems. Farms with CMS and sensor systems had more cows than CMS farms without sensor systems. Furthermore, farms with sensor systems had fewer labor hours per cow compared with farms without sensor systems. Other farm characteristics (age of the farmer, availability of a successor, growth in herd size, milk production per cow, number of cows per hectare, and milk production per hectare) did not differ for farms with and without sensor systems.

Key words: dairy, sensor, survey, investment

\section{INTRODUCTION}

To improve cow management in large dairy herds, sensors have been developed that can measure physiological, behavioral, and production indicators on individual cows. Previously, a sensor was defined as a device that measures a physiological or behavioral parameter (related to the health or estrus) of an individual cow and enables automated, on-farm detection of changes in this condition that is related to a health event and requires action on the part of the farmer (Rutten et al., 2013). In recent years, many sensors have been developed. For instance, sensors can measure milk, fat, and protein yields (Katz et al., 2007) and milk components to monitor cow fertility (Friggens and Chagunda, 2005; Posthuma-Trumpie et al., 2009) and udder health (Espada and Vijverberg, 2002; Whyte et al., 2004; Kamphuis et al., 2008). Activity meters, pedometers, and 3-dimensional accelerometers have been developed to improve and automate the detection of estrus (e.g., Firk et al., 2002; O'Connell et al., 2010; Holman et al., 2011) and lameness (Pastell et al., 2009; Chapinal et al., 2010; Miekley et al., 2012). Recently, sensor systems have been developed that measure the weight of cows (van der Tol and van der Kamp, 2010) and rumination time (Bar and Solomon, 2010; Büchel and Sundrum, 2014), and other sensor systems are currently under development.

Recently, the number of dairy farms using sensor systems has increased, especially the use of sensor systems to automate the detection of estrus. It is believed that approximately $20 \%$ of the Dutch farms use automated 
estrus detection (H. Knijn, CRV, Arnhem, the Netherlands; personal communication). In the Netherlands and other northwest European countries, the use of sensors is increasing because of the growing use of automatic milking systems (AMS). Because a milker is not present during the automatic milking process to judge the udder and milk for abnormalities, AMS include sensors for the detection of mastitis. An increasing number of other sensor systems can be combined with an AMS, such as a weighing platform to monitor the weight of the cows (van der Tol and van der Kamp, 2010).

Labor reduction is one the most important reasons to invest in sensor systems because individual cow monitoring by physical observations by the farmer becomes challenging in large herds. In northwest Europe, labor is expensive and farmers are looking for ways to replace physical labor. Sensor systems for estrus detection can reduce labor by eliminating the need to observe the cows for estrus. For instance, to detect estrus, it is advised to observe cows 3 times per day for 20 min (Firk et al., 2002). When using a sensor system for estrus detection, this labor time can be reduced, but an estimate on how much time can be saved is not known. An expected improvement in disease and estrus detection can also be a reason to invest in sensor systems. Several studies indicate that sensor systems detect approximately 80 to $85 \%$ of the cows in estrus (e.g., Hockey et al., 2010; Kamphuis et al., 2012), whereas the average farmer detects approximately $55 \%$ of the cows in estrus (Firk et al., 2002). Probably, expected higher farm profitability is a reason to invest in sensor systems. The economic consequences of investing in sensor systems was investigated by use of developed normative models (Bewley et al., 2010; Rutten et al., 2014), and applying sensor systems resulted in more timely and informed decisions and, consequently, a higher profitability for the farm.

Many sensor systems are available today. It is not known, however, which systems are used on dairy farms and which systems are rarely used. Moreover, the reasons why farmers invest (or not) in sensor systems remain unclear. To date, studies on reasons for investing in new technologies on dairy farms have focused especially on investing in an AMS. Labor reduction and more flexible labor time were the most important reasons for investing in an AMS (Mathijs, 2004). Only Russell and Bewley (2013) investigated the reasons for not investing in sensor systems on US dairy farms, and they found that the most important reasons for not investing were being unfamiliar with available technologies, an undesirable cost-benefit ratio, and too much information being provided without knowing what to do with it.

The first objective of this study was to give an overview of the sensor systems currently used in the
Netherlands on both AMS and conventional milking system (CMS) farms. The second objective was to investigate the reasons for investing and not investing in sensor systems. The third objective was to characterize farms with and without sensor systems, taking into account farm size, milk production level, intensiveness of the farm, growth in herd size, age of the farmer, and whether a successor is available. The analyses were based on data from 512 Dutch dairy farms.

\section{MATERIALS AND METHODS}

\section{Data Collection}

A survey was developed to investigate reasons for investing and not investing in sensor systems, and to investigate how sensor systems are used in daily cow management. The first question was whether the farm had a sensor system, and subsequent questions differed for farms with and without sensor systems. The survey for farms without sensor systems had 13 questions, and the number of questions for farms with sensor systems depended on the number of sensor systems at the farm. For each different sensor system, there were questions about whether the sensor system was part of an AMS, year of investment, reason for investment, whether the investment occurred together with another major change at the farm, and the extent of use of the sensor system. All farmers had to answer questions about the age of the farmer, whether a successor was available, total labor hours at the farm, and whether they had plans for future investment in a sensor system. All questions were closed questions, except for age of the farmer and total labor hours.

The survey was developed by using Qualtrics software (Qualtrics, Provo, UT). The survey (in Dutch) is available upon request from the authors. A link to the survey was sent by e-mail to 1,672 Dutch dairy farmers. The list with e-mail addresses was provided by a Dutch accounting agency (Accon AVM, Leeuwarden, the Netherlands). This agency is one of the largest farm accounting agencies in the Netherlands. The farms were located all over the Netherlands, but most were located in the north of the country. The e-mail with the link to the survey was sent on October 18, 2013, and the deadline to complete it was November 17, 2013. During that time, 2 reminders were sent to farmers who had not yet completed it.

In total, 532 farmers completed the survey. Twenty farms were deleted because they indicated that they no longer kept dairy cows $(n=15)$ or because they wrongly indicated that they had sensor systems $(\mathrm{n}=5)$. The final data set consisted of 512 dairy farms (response rate of $30.6 \%$ ); 202 farmers indicated that they had one 
or more sensor systems and 310 farmers indicated that they did not have any sensor systems. The farm accounting agency provided additional information about 491 farms (number of dairy cows, hectares, and total amount (kg) of milk delivered per year). This means that analysis on the farm characterization was based on 491 farms.

\section{Data Analysis}

Data were transferred from Qualtrics into SAS software (version 9.3; SAS Institute Inc., Cary, NC), and all data editing and analyses were conducted using SAS. In this study, 3 farm types were defined (farms without sensor systems, AMS farms with sensor systems, and CMS farms with sensor systems). This classification was made because we expected that CMS farms with sensor systems would have different reasons for investing and using the sensor systems compared with AMS farms because investments on CMS farms were made deliberately, whereas on AMS farms, the sensors became available with the investment in the AMS. Descriptive statistics and comparisons of the 3 types of farms were performed using PROC GLM.

A linear discriminant analysis was performed to characterize farms with and without sensor systems. A linear discriminant analysis performs a multivariate test of differences between groups and can provide a linear function of those farm characteristics that best separate farms with and without sensor systems. In this study, the classification variable contained the 3 farm types, and 8 farm characteristic variables (age of the farmer, successor available, number of dairy cows, growth in herd size in percentage difference in number of cows between 2013 and 2012, milk production per cow per year, number of cows per hectare, milk production per hectare, and labor hours per cow per week) were analyzed to derive canonical variables. Canonical variables were linear combinations of the farm characteristics variables that contained the highest possible multiple correlation with each farm class. The coefficients of the linear combination were the canonical coefficients. The variable defined by the linear combination was the first canonical variable. The second canonical correlation was obtained by finding the linear combination uncorrelated with the first canonical variable that had the highest possible multiple correlation with the classes. The process of extracting canonical variables can be repeated until the number of canonical variables equals the number of original variables or the number of classes minus one. Stepwise discriminant analysis using PROC STEPDISC was used to determine the best combination of variables that would separate the 3 groups of farms. Subsequently, the selected variables were used in PROC CANDISC to derive canonical coefficients.

\section{RESULTS AND DISCUSSION}

\section{Available Farms}

The farms in our data set were larger than the Dutch average of 91 cows (LEI, 2013), whereas milk production level was slightly lower compared with the Dutch average of $8,217 \mathrm{~kg} /$ cow per year (CRV, 2013; Table 1). The CMS farms had more cows than AMS farms, most likely because AMS units can milk a maximum number of cows and thus AMS farms have a limitation on the number of cows, making herd expansion difficult. The average size of Dutch dairy farms is 52 ha (LEI, 2013), which means, on average, 1.75 cows per hectare and $14,380 \mathrm{~kg}$ of milk per hectare. The farms in our data set were slightly less intensive (Table 1), probably because most farms were located in the north of the country, which is known for having fewer cows per hectare compared with other parts of the country (CBS, 2012). Total labor hours at the farm averaged 1.19 labor hours per cow per week on farms without sensor systems, and 0.92 labor hours on AMS farms (Table 1). Labor

Table 1. Average (SD in parentheses) herd characteristics about the farms without sensor systems, with sensor systems on an automatic milking system (AMS), and with sensor systems on farms with conventional milking systems (CMS)

\begin{tabular}{|c|c|c|c|}
\hline Item & $\begin{array}{l}\text { Farms without } \\
\text { sensor systems } \\
\quad(\mathrm{n}=310)\end{array}$ & $\begin{array}{l}\text { AMS farms with } \\
\text { sensor systems } \\
(\mathrm{n}=121)\end{array}$ & $\begin{array}{l}\text { CMS farms with } \\
\text { sensor systems } \\
\quad(\mathrm{n}=81)\end{array}$ \\
\hline Age of the farmer (yr) & $47.5^{\mathrm{a}}(9.5)$ & $47.8^{\mathrm{a}}(8.9)$ & $45.3^{\mathrm{a}}(9.6)$ \\
\hline Number of dairy cows & $90^{\mathrm{a}}(41)$ & $104^{\mathrm{a}}(49)$ & $123^{\mathrm{b}}(61)$ \\
\hline Growth in herd size ${ }^{1}(\%)$ & $3.67^{\mathrm{a}}(9.39)$ & $4.28^{\mathrm{a}}(8.38)$ & $3.62^{\mathrm{a}}(10.38)$ \\
\hline Milk production (kg/cow per year) & $7,764^{\mathrm{a}}(1,149)$ & $7,986^{\mathrm{a}}(1,029)$ & $7,982^{\mathrm{a}}(1,046)$ \\
\hline Number of cows per hectare & $1.66^{\mathrm{a}}(0.43)$ & $1.71^{\mathrm{a}}(0.45)$ & $1.67^{\mathrm{a}}(0.39)$ \\
\hline Milk production per hectare $(\mathrm{kg})$ & $12,900^{\mathrm{a}}(3,982)$ & $13,625^{\mathrm{a}}(3,865)$ & $13,157^{\mathrm{a}}(3,370)$ \\
\hline Labor hours per cow per week & $1.19^{\mathrm{a}}(0.55)$ & $0.92^{b}(0.37)$ & $0.95^{\mathrm{b}}(0.39)$ \\
\hline
\end{tabular}


hours varying between 0.77 and 1.82 per cow per week for farms with increasing herd sizes were reported for dairy farms in Ontario, but these estimates excluded fieldwork associated with feed production (Rodenburg and Lang, 2010).

At least one sensor system was available on $39 \%$ of the responding farms. This percentage cannot be compared with other studies because it is not known how many farms have sensor systems. In our study, $24 \%$ of the farms milked with an AMS, a value higher than previously reported (Steeneveld et al., 2012). Our study had a selection bias because the farms in our study were connected to an accounting agency, and such farms are typically interested in understanding their financial performance to assist in making better management decisions. Moreover, farmers completed the questionnaire voluntarily. We can assume that farmers in our study were more interested in new technologies to enhance management decisions and therefore that the percentage of farms with an AMS or sensor systems was higher than the Dutch average. Information on sensor systems was not available for nonrespondents. If we assume, however, that nonrespondents had no sensor systems, we can expect that at least $12 \%(202 / 1,672)$ of the farms had sensor systems.

\section{Overview of Sensor Systems}

An overview of the available sensor systems on both AMS and CMS farms is presented in Table 2. Most investments took place in recent years, especially on farms with a CMS (Table 3). The most common sensors on AMS farms were those to measure the color and electrical conductivity of milk (Table 2). These systems are used for the detection of mastitis, and it is therefore logical that these sensor systems are most common on
AMS farms. The weighing platform, fat and protein sensors, SCC sensor, and milk temperature sensors were predominately present on AMS farms (Table 2). In total, $41 \%$ of the AMS farms had activity meters and pedometers for dairy cows, and $70 \%$ of the CMS farms with sensor systems had activity meters and pedometers for dairy cows (Table 2).

\section{Reasons for Investing in Sensor Systems}

It was often not a conscious decision to invest in mastitis detection sensor systems on AMS farms, because the most common reasons to invest in such systems were that they were included as standard with AMS or that they could be purchased at reduced cost with the AMS (Table 4). The weighing platform, fat and protein sensors, SCC sensor, and milk temperature sensors can easily be attached to the AMS and are often optional when buying an AMS, as seen in the reasons for investing in these sensor systems. The most common reasons were that they were included as standard with the AMS or were bought at reduced cost (Tables 4 and 5). The main reasons for investing in activity meters and pedometers for dairy cows were to improve detection, improve profitability of the farm, and gain insight into the fertility level of the herd. For activity meters and pedometers for young stock, the farmers had the same reasons to invest (Table 6). It is not surprising that the farmers mention these reasons for investment in activity meters and pedometers. Activity meters and pedometers increase estrus detection performance (e.g., Hockey et al., 2010; Kamphuis et al., 2012), and investments in activity meters are profitable (Rutten et al., 2014). Reducing labor was a frequently mentioned reason for investment in activity meters and pedometers by farmers with a CMS (Table 6). By not visually

Table 2. Overview of used sensor systems at farms with an automatic milking system (AMS) and a conventional milking system (CMS)

\begin{tabular}{lcc}
\hline Type of sensor system at the farm & $\begin{array}{c}\text { No. (\%) of AMS } \\
\text { farms (n=121) }\end{array}$ & $\begin{array}{c}\text { No. (\%) of CMS } \\
\text { farms (n = 81) }\end{array}$ \\
\hline Color sensor & $72(60)$ & $1(1)$ \\
SCC sensor & $21(17)$ & $1(1)$ \\
Electrical conductivity sensor & $112(93)$ & $28(35)$ \\
Weighing platform & $33(27)$ & $4(5)$ \\
Rumination activity sensor & $11(9)$ & $10(12)$ \\
Activity meters and pedometers for young stock & $14(12)$ & $23(28)$ \\
Activity meters and pedometers for dairy cows & $50(41)$ & $57(70)$ \\
Fat and protein sensor & $24(20)$ & $0(0)$ \\
Temperature sensor & $7(6)$ & $11(14)$ \\
Milk temperature sensor & $56(46)$ & $4(5)$ \\
Progesterone sensor & $2(2)$ & $1(1)$ \\
Urea sensor & $2(2)$ & $1(1)$ \\
Lactate dehydrogenase (LDH) sensor & $3(2)$ & $1(1)$ \\
$\beta$-Hydroxybutyrate (BHB) sensor & $3(2)$ & $1(1)$ \\
Other sensor systems & $4(3)$ & $8(10)$ \\
\hline
\end{tabular}


Table 3. Overview of the year of investment for 7 sensor systems on farms with an automatic milking system (AMS) and a conventional milking system (CMS)

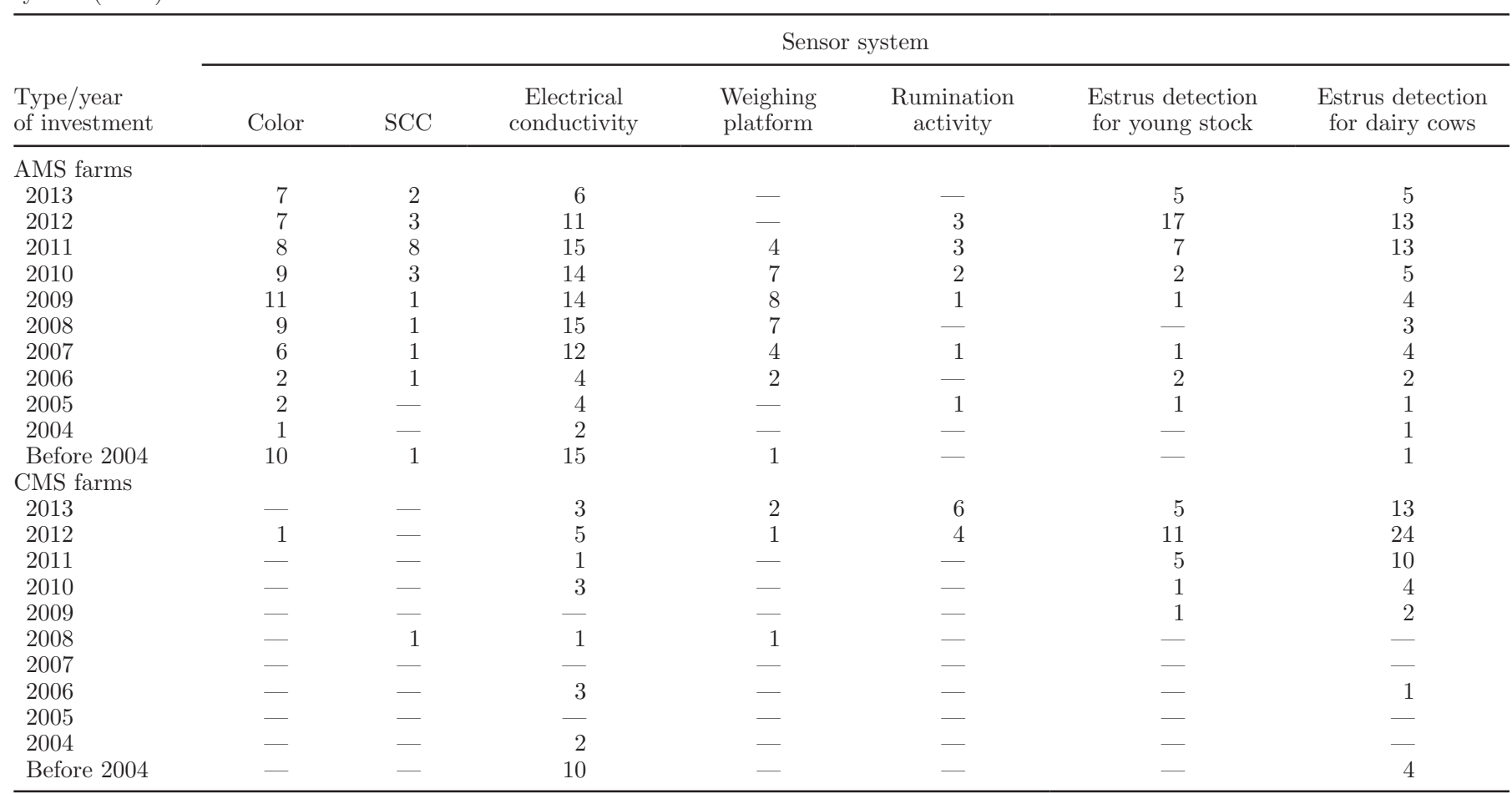

checking cows for estrus, a farmer can reduce labor, and labor time can be reduced further by inseminating cows without visual confirmation of estrus.

\section{Use of Sensor Systems}

Around $40 \%$ of the farmers never or sometimes used the output of the color sensors and the weighing platform, whereas about $40 \%$ the farmers used the output of these sensor systems frequently or daily (Tables 7 and 8). The color sensors and the weighing platform are usually included as standard in the AMS, and results show that the use of these systems was very variable. The sensors for measuring fat and protein and milk temperature were the least-used sensor systems: more than $50 \%$ of farmers indicated that they never or only sometimes used the output of these sensor systems (Table 8). The sensors for measuring SCC, electri-

Table 4. Reasons for investing in color sensors, SCC sensors, and electrical conductivity sensors for farms with an automatic milking system (AMS) and a conventional milking system (CMS)

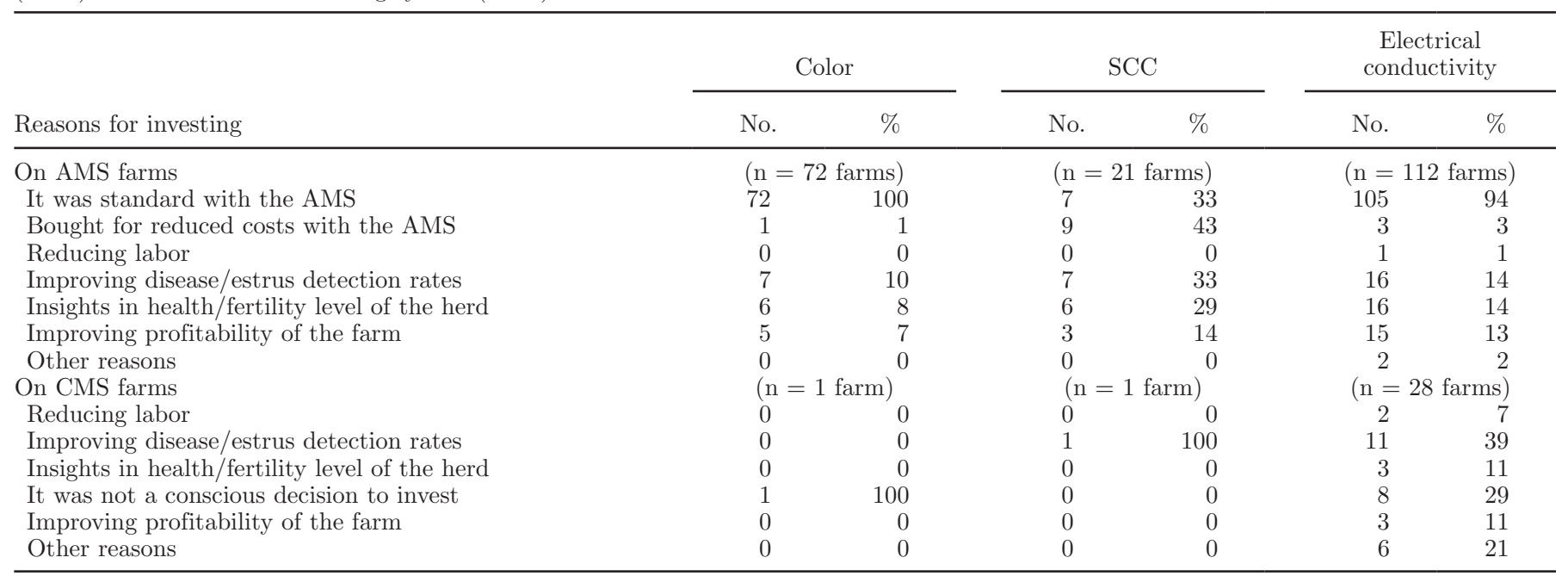


Table 5. Reasons for investing in a weighing platform, rumination activity sensors, fat and protein sensors, and milk temperature sensors for farms with an automatic milking system (AMS) and a conventional milking system (CMS)

\begin{tabular}{|c|c|c|c|c|c|c|c|c|}
\hline \multirow[b]{2}{*}{ Reason for investing } & \multicolumn{2}{|c|}{$\begin{array}{l}\text { Weighing } \\
\text { platform }\end{array}$} & \multicolumn{2}{|c|}{$\begin{array}{l}\text { Rumination } \\
\text { activity }\end{array}$} & \multicolumn{2}{|c|}{$\begin{array}{l}\text { Fat and } \\
\text { protein sensor }\end{array}$} & \multicolumn{2}{|c|}{$\begin{array}{c}\text { Milk } \\
\text { temperature }\end{array}$} \\
\hline & No. & $\%$ & No. & $\%$ & No. & $\%$ & No. & $\%$ \\
\hline On AMS farms & \multicolumn{2}{|c|}{$(\mathrm{n}=33$ farms $)$} & \multicolumn{2}{|c|}{$(\mathrm{n}=11$ farms $)$} & \multicolumn{2}{|c|}{$(\mathrm{n}=24$ farms $)$} & \multicolumn{2}{|c|}{$(\mathrm{n}=56$ farms $)$} \\
\hline It was standard with the AMS & 31 & 94 & 2 & 18 & 10 & 42 & 50 & 89 \\
\hline Bought for reduced costs with the AMS & 1 & 3 & 4 & 36 & 9 & 38 & 2 & 4 \\
\hline Reducing labor & 0 & 0 & 1 & 9 & 0 & 0 & 1 & 2 \\
\hline Improving profitability of the farm & 4 & 12 & 5 & 45 & 7 & 29 & 9 & 16 \\
\hline Other reasons & 1 & 3 & 0 & 0 & 1 & 4 & 2 & 4 \\
\hline On CMS farms & \multicolumn{2}{|c|}{$(\mathrm{n}=4$ farms $)$} & \multicolumn{2}{|c|}{$(\mathrm{n}=10$ farms $)$} & & & \multicolumn{2}{|c|}{$(\mathrm{n}=4$ farms $)$} \\
\hline Reducing labor & 0 & 0 & 3 & 30 & & & 0 & 0 \\
\hline Improving disease/estrus detection rates & 1 & 25 & 7 & 70 & & & 1 & 25 \\
\hline Insights in health/fertility level of the herd & 0 & 0 & 6 & 60 & & & 0 & 0 \\
\hline It was not a conscious decision to invest & 0 & 0 & 1 & 10 & & & 2 & 50 \\
\hline
\end{tabular}

cal conductivity, rumination activity, and activity for young stock were frequently used: more than $75 \%$ of the farmers indicated that they used the output of these sensor systems frequently or daily (Tables 7,8 , and 9). The output of activity meters and pedometers for dairy cows was intensively used (Table 9).

\section{Reasons for Not Investing in Sensor Systems}

The most important reasons for not investing in sensor systems were economically related, with "prefer to invest money in other things for the farm" and "uncertainty about the profitability of the investment" being the most mentioned reasons (Table 10). These results are in agreement with Russell and Bewley (2013), who found that uncertainty about the profitability of an investment was an important factor for not investing in automated monitoring technologies on dairy farms. Russell and Bewley (2013) found that the most important reason for not investing was that farmers are not familiar with technologies that are available. This reason was mentioned by only $6 \%$ of the farmers in the current study (Table 10). Probably, Dutch farmers are well informed about new technologies through magazines and meetings. We investigated whether reasons for not investing differed between different groups of farms (differing in age of the farmer, herd size, production level, intensiveness of the farm, and availability of a successor). Especially young dairy farmers and farms with a successor reported that they wait for improved versions of the sensor systems. Other reasons did not differ between different types of farms (results not shown).

Table 6. Reasons for investing in activity meters and pedometers for young stock and dairy cows for farms with an automatic milking system (AMS) and a conventional milking system (CMS)

\begin{tabular}{|c|c|c|c|c|}
\hline \multirow[b]{2}{*}{ Reasons for investing } & \multicolumn{2}{|c|}{ Young stock } & \multicolumn{2}{|c|}{ Dairy cows } \\
\hline & No. & $\%$ & No. & $\%$ \\
\hline On AMS farms & \multicolumn{2}{|c|}{$(\mathrm{n}=14$ farms $)$} & \multicolumn{2}{|c|}{$(\mathrm{n}=50$ farms $)$} \\
\hline It was standard with the AMS & 0 & 0 & 9 & 18 \\
\hline Bought for reduced costs with the AMS & 4 & 29 & 15 & 30 \\
\hline Reducing labor & 0 & 0 & 3 & 6 \\
\hline Improving estrus detection rates & 9 & 64 & 36 & 72 \\
\hline Insights in fertility level of the herd & 5 & 36 & 21 & 42 \\
\hline Improving profitability of the farm & 9 & 64 & 24 & 48 \\
\hline Other reasons & 1 & 7 & 0 & 0 \\
\hline On CMS farms & \multicolumn{2}{|c|}{$(\mathrm{n}=23$ farms $)$} & \multicolumn{2}{|c|}{$(\mathrm{n}=57$ farms $)$} \\
\hline Reducing labor & 12 & 52 & 22 & 39 \\
\hline Improving estrus detection rates & 21 & 91 & 46 & 81 \\
\hline Insights in fertility level of the herd & 8 & 35 & 26 & 46 \\
\hline It was not a conscious decision to invest & 0 & 0 & 2 & 4 \\
\hline Improving profitability of the farm & 12 & 52 & 27 & 47 \\
\hline Other reasons & 2 & 9 & 3 & 5 \\
\hline
\end{tabular}


Table 7. Extent of use of color sensors, SCC sensors, and electrical conductivity sensors for farms with an automatic milking system (AMS) and a conventional milking system (CMS)

\begin{tabular}{|c|c|c|c|c|c|c|}
\hline \multirow[b]{2}{*}{ Extent of use } & \multicolumn{2}{|c|}{ Color } & \multicolumn{2}{|c|}{$\mathrm{SCC}$} & \multicolumn{2}{|c|}{$\begin{array}{c}\text { Electrical } \\
\text { conductivity }\end{array}$} \\
\hline & No. & $\%$ & No. & $\%$ & No. & $\%$ \\
\hline On AMS farms & \multicolumn{2}{|c|}{$(\mathrm{n}=72$ farms $)$} & \multicolumn{2}{|c|}{$(\mathrm{n}=21$ farms $)$} & \multicolumn{2}{|c|}{$(\mathrm{n}=112$ farms } \\
\hline Never & 5 & 7 & 0 & 0 & 0 & 0 \\
\hline Sometimes & 30 & 42 & 1 & 5 & 5 & 5 \\
\hline Regularly & 9 & 13 & 3 & 15 & 8 & 7 \\
\hline Frequently & 5 & 7 & 5 & 25 & 13 & 12 \\
\hline Daily & 23 & 32 & 11 & 55 & 85 & 77 \\
\hline On CMS farms & \multicolumn{2}{|c|}{$(\mathrm{n}=1$ farm $)$} & \multicolumn{2}{|c|}{$(\mathrm{n}=1$ farm $)$} & \multicolumn{2}{|c|}{$(\mathrm{n}=28$ farms $)$} \\
\hline Never & 1 & 100 & 0 & 0 & 7 & 25 \\
\hline Sometimes & 0 & 0 & 0 & 0 & 6 & 21 \\
\hline Regularly & 0 & 0 & 1 & 100 & 6 & 21 \\
\hline Frequently & 0 & 0 & 0 & 0 & 3 & 11 \\
\hline Daily & 0 & 0 & 0 & 0 & 6 & 21 \\
\hline
\end{tabular}

\section{Characterization of Farms With and Without Sensor Systems}

The stepwise selection of farm characteristics resulted in 3 selected farm characteristics (number of cows, labor hours per cow per week, and the number of cows per hectare). Using these variables in the linear discriminant analysis resulted in canonical coefficients (Table 11). The first canonical variable explained $8.8 \%$ of the total variation, which is considered very low. By adding the second canonical variable, in total $10.7 \%$ of the total variation could be explained, which is still very low. By not performing the stepwise selection and including all farm characteristics, a comparable explained variation was reached (results not shown). It was thus very difficult to characterize farms with and without sensor systems. From the descriptive statistics, it can be seen that there were few differences between the 3 types of farms (Table 1). Only the number of cows was signifi- cantly higher on CMS farms with sensor systems than on farms without sensor systems. Most likely, farms with sensor systems are more forward thinking and are therefore larger than those without sensor systems. Moreover, larger farms especially have a need to support cow management, which can be done with sensor systems. The number of labor hours per cow per week was lower on farms with sensor systems than on farms without sensor systems, suggesting that having a sensor system reduces labor time. Having a successor was not included in the final linear discriminant analysis. In the descriptive statistics, we observed no significant difference in having a successor between farms with and without sensor systems (results not shown).

It would be interesting to investigate which farms do and which do not invest in sensor systems. To determine adoption factors, farm characteristics about the year of investment were needed, as collected by Sauer and Zilberman (2012). Unfortunately, farm characteris-

Table 8. Extent of use of a weighing platform, rumination activity sensors, fat and protein sensors, and milk temperature sensors for farms with an automatic milking system (AMS) and a conventional milking system (CMS)

\begin{tabular}{|c|c|c|c|c|c|c|c|c|}
\hline \multirow[b]{2}{*}{ Extent of use } & \multicolumn{2}{|c|}{ Weighing platform } & \multicolumn{2}{|c|}{$\begin{array}{c}\text { Rumination } \\
\text { activity }\end{array}$} & \multicolumn{2}{|c|}{$\begin{array}{l}\text { Fat and protein } \\
\text { sensor }\end{array}$} & \multicolumn{2}{|c|}{ Milk temperature } \\
\hline & No. & $\%$ & No. & $\%$ & No. & $\%$ & No. & $\%$ \\
\hline On AMS farms & \multicolumn{2}{|c|}{$(\mathrm{n}=33$ farms $)$} & \multicolumn{2}{|c|}{$(\mathrm{n}=11$ farms $)$} & \multicolumn{2}{|c|}{$(\mathrm{n}=24$ farms $)$} & \multicolumn{2}{|c|}{$(\mathrm{n}=56$ farms $)$} \\
\hline Never & 2 & 6 & 0 & 0 & 3 & 13 & 12 & 21 \\
\hline Sometimes & 11 & 33 & 1 & 9 & 12 & 50 & 18 & 32 \\
\hline Regularly & 9 & 27 & 0 & 0 & 3 & 13 & 11 & 20 \\
\hline Frequently & 4 & 12 & 1 & 9 & 2 & 8 & 9 & 16 \\
\hline Daily & 7 & 21 & 9 & 82 & 4 & 17 & 6 & 11 \\
\hline On CMS farms & \multicolumn{2}{|c|}{$(\mathrm{n}=4$ farms $)$} & \multicolumn{2}{|c|}{$(\mathrm{n}=10$ farms $)$} & & & \multicolumn{2}{|c|}{$(\mathrm{n}=4$ farms $)$} \\
\hline Never & 1 & 25 & 0 & 0 & & & 2 & 50 \\
\hline Sometimes & 1 & 25 & 1 & 10 & & & 2 & 50 \\
\hline Regularly & 0 & 0 & 5 & 50 & & & 0 & 0 \\
\hline Frequently & 0 & 0 & 0 & 0 & & & 0 & 0 \\
\hline Daily & 2 & 50 & 4 & 40 & & & 0 & 0 \\
\hline
\end{tabular}


Table 9. Extent of use of activity meters and pedometers for young stock and dairy cows for farms with an automatic milking system (AMS) and a conventional milking system (CMS)

\begin{tabular}{|c|c|c|c|c|}
\hline \multirow[b]{2}{*}{ Extent of use } & \multicolumn{2}{|c|}{ Young stock } & \multicolumn{2}{|c|}{ Dairy cows } \\
\hline & No. & $\%$ & No. & $\%$ \\
\hline On AMS farms & \multicolumn{2}{|c|}{$(\mathrm{n}=14$ farms $)$} & \multicolumn{2}{|c|}{$(\mathrm{n}=50$ farms $)$} \\
\hline Never & 1 & 7 & 0 & 0 \\
\hline Sometimes & 2 & 14 & 3 & 6 \\
\hline Regularly & 0 & 0 & 3 & 6 \\
\hline Frequently & 0 & 0 & 7 & 14 \\
\hline Daily & 11 & 79 & 37 & 74 \\
\hline On CMS farms & \multicolumn{2}{|c|}{$(\mathrm{n}=23$ farms $)$} & \multicolumn{2}{|c|}{$(\mathrm{n}=57$ farms $)$} \\
\hline Never & 2 & 9 & 1 & 2 \\
\hline Sometimes & 1 & 4 & 2 & 4 \\
\hline Regularly & 2 & 9 & 2 & 4 \\
\hline Frequently & 2 & 9 & 10 & 18 \\
\hline Daily & 16 & 70 & 42 & 74 \\
\hline
\end{tabular}

tics data was available only from years 2012 and 2013. Therefore, only a current characterization of farms with and without sensor systems was performed.

\section{Economic Implications}

Improving profitability of the farm was frequently mentioned as a reason to invest (Tables 4, 5, and 6), and the main reasons for not investing were economically related as well (Table 10). These results emphasize the importance of research on the economic consequences of investments in sensor systems. Dairy farmers will only invest in sensor systems if the benefits are clear. So far, the economic consequences of investing in automated estrus detection and concentrate feeding (van Asseldonk et al., 1999), automated body condition scoring systems (Bewley et al., 2010), and activity meters for estrus detection (Rutten et al., 2014) have been investigated only by use of normative models. It will be interesting to determine the economic consequences of investing in sensor systems by analyzing actual farm data (e.g., farm accounting data). These empirical investigations were performed for AMS investments (Bijl et al., 2007; Steeneveld et al., 2012), and the same analysis techniques can be applied to farms with and without sensor systems. To date, research on sensor systems has focused on the development of the sensors and detection performance (Rutten et al., 2013). It is not known, however, whether using sensor systems also improves technical parameters of the farm, such as milk production, first calving age, calving interval, disease incidence, and SCC.

\section{CONCLUSIONS}

A survey was conducted among 512 Dutch dairy farmers to collect information on whether they use sensor systems $(\mathrm{n}=310)$ or not $(\mathrm{n}=202)$ for cow management. Sensor systems for mastitis detection and estrus detection were the most-used sensor systems. Reasons for investing were different for different sensor systems. For sensor systems attached to the AMS, farmers made no conscious decision to invest because the sensors were included as standard with the AMS or were purchased for reduced cost with the AMS. Main reasons for investing in estrus detection sensor systems were to improve detection rates, gain insight into the fertility level of the herd, improve profitability of the

Table 10. Reasons for not investing in sensor systems indicated by 310 Dutch dairy farmers

\begin{tabular}{lrc}
\hline Reason for not investing & No. & $\%$ \\
\hline Prefer to invest money in other things for the farm & 149 & 48 \\
Uncertainty about the profitability of the investment & 119 & 38 \\
Poor integration with other farm systems and software & 40 & 13 \\
Waiting for improved versions of sensor systems & 29 & 9 \\
There are better alternatives to improve daily management & 24 & 8 \\
There is too much information provided without knowing what to do with it & 24 & 8 \\
Not familiar with sensor systems that are available & 20 & 6 \\
Not enough time to work with sensor systems & 11 & 4 \\
Poor technical support or training & 6 & 2 \\
Too difficult or complex to use & 4 & 2 \\
Sensor systems are not reliable & 3 & 1 \\
Sensor systems are not useful & 3 \\
\hline
\end{tabular}


Table 11. Canonical coefficients and total variation explained by each canonical variable (Can)

\begin{tabular}{lcc}
\hline Farm characteristic & Can 1 & Can 2 \\
\hline Number of cows & -0.6821 & 0.9057 \\
Labor hours per cow per week & 0.5723 & 0.9074 \\
Number of cows per hectare & 0.3355 & -0.4269 \\
Variation $(\%)$ & 8.8 & 1.9 \\
\hline
\end{tabular}

farm, and reduce labor. The main reasons for not investing in sensor systems were related to economics. It was very difficult to characterize farms with and without sensor systems, although CMS farms with sensor systems had more cows than CMS farms without sensor systems. Furthermore, farms with sensor systems used fewer labor hours per cow than farms without sensor systems. Other farm characteristics (age of the farmer, availability of a successor, growth in herd size, milk production per cow, number of cows per hectare, and milk production per hectare) did not differ for farms with and without sensor systems.

\section{ACKNOWLEDGMENTS}

The authors thank the dairy farmers for completing the survey and Accon AVM (Leeuwarden, the Netherlands) for providing data about the farms. This research was supported by NWO (Netherlands Organization for Scientific Research, The Hague, the Netherlands).

\section{REFERENCES}

Bar, D., and R. Solomon. 2010. Rumination collars: What can they tell us? Pages 214-215 in Proc. First North Am. Conf. Precision Dairy Management, Toronto, Canada.

Bewley, J. M., M. D. Boehlje, A. W. Gray, H. Hogeveen, S. J. Kenyon, S. D. Eicher, and M. M. Schutz. 2010. Assessing the potential value for an automated dairy cattle body condition scoring system through stochastic simulation. Agric. Fin. Rev. 70:126-150.

Bijl, R., S. R. Kooistra, and H. Hogeveen. 2007. The profitability of automatic milking on Dutch dairy farms. J. Dairy Sci. 90:239-248.

Büchel, S., and A. Sundrum. 2014. Short communication: Decrease in rumination time as an indicator of the onset of calving. J. Dairy Sci. 97:3120-3127.

CBS. 2012. Statistics Netherlands. Accessed May 16, 2014. http:// www.cbs.nl/nl-NL/menu/themas/landbouw/cijfers/incidenteel/ maatwerk/default.htm

Chapinal, N., A. M. de Passille, J. Rushen, and S. Wagner. 2010. Automated methods for detecting lameness and measuring analgesia in dairy cattle. J. Dairy Sci. 93:2007-2013.

CRV. 2013. Annual report 2013. CRV, Arnhem, the Netherlands.

Espada, E., and H. Vijverberg. 2002. Milk colour analysis as a tool for the detection of abnormal milk. Pages 28-38 in Proc. First North Am. Conf. Robotic Milking, Toronto, Canada.

Firk, R., E. Stamer, W. Junge, and J. Krieter. 2002. Automation of oestrus detection in dairy cows: A review. Livest. Prod. Sci. $75: 219-232$.

Friggens, N. C., and M. G. G. Chagunda. 2005. Prediction of the reproductive status of cattle on the basis of milk progesterone measures: Model description. Theriogenology 64:155-190.

Hockey, C. D., J. M. Morton, S. T. Norman, and M. R. McGowan. 2010. Evaluation of a neck mounted 2-hourly activity meter sys- tem for detecting cows about to ovulate in two paddock-based Australian dairy herds. Reprod. Domest. Anim. 45:e107-e117.

Holman, A., J. Thompson, J. E. Routly, J. Cameron, D. N. Jones, D. Grove-White, R. F. Smith, and H. Dobson. 2011. Comparison of oestrus detection methods in dairy cattle. Vet. Rec. 169:47.

Kamphuis, C., B. DelaRue, C. R. Burke, and J. Jago. 2012. Field evaluation of 2 collar-mounted activity meters for detecting cows in estrus on a large pasture-grazed dairy farm. J. Dairy Sci. 95:3045-3056.

Kamphuis, C., D. Pietersma, R. van der Tol, M. Wiedemann, and H. Hogeveen. 2008. Using sensor data patterns from an automatic milking system to develop predictive variables for classifying clinical mastitis and abnormal milk. Comput. Electron. Agric. 62:169-181.

Katz, G., A. Arazi, N. Pinsky, I. Halachmi, Z. Schmilovitz, E. Aizinbud, and E. Maltz. 2007. Current and near term technologies for automated recording of animal data for precision dairy farming. J. Anim. Sci. 85:377.

LEI. 2013. Agricultural Economics Research Institute. Agricultural statistics. Accessed May 16, 2014. http://www3.lei.wur.nl/BIN _ASP $/$ show.exe? aktie $=$ vindtoon $\& b j=2010 \& e j=2013 \&$ language $=$ NL\&Valuta $=2 \&$ publicatieID $=3 \&$ kiestabel $=2.02 \&$ Database $=$ LTC

Mathijs, E. 2004. Socio-economic aspects of automatic milking. Pages 46-55 in Proc. Int. Symp. Automatic Milking: A Better Understanding, A. Meijering, H. Hogeveen, and C. J. A. M. de Koning, ed. Wageningen Academic Publishers, Wageningen, the Netherlands,.

Miekley, B., I. Traulsen, and J. Krieter. 2012. Detection of mastitis and lameness in dairy cows using wavelet analysis. Livest. Sci. $148: 227-236$

O'Connell, J., F. A. Tøgersen, N. C. Friggens, P. Løvendahl, and S. Højsgaard. 2010. Combining cattle activity and progesterone measurements using hidden semi-Markov models. J. Agric. Biol. Environ. Stat. 16:1-16.

Pastell, M., J. Tiusanen, M. Hakojarvi, and L. Hanninen. 2009. A wireless accelerometer system with wavelet analysis for assessing lameness in cattle. Biosystems Eng. 104:545-551.

Posthuma-Trumpie, G. A., A. van Amerongen, J. Korf, and W. J. H. van Berkel. 2009. Perspectives for on-site monitoring of progesterone. Trends Biotechnol. 27:652-660.

Rodenburg, J., and B. Lang. 2010. Labour costs on Ontario dairy farms and their implications for precision technologies. Pages 2021 in Proc. First North Am. Conf. Precision Dairy Management, Toronto, Canada.

Russell, R. A., and J. M. Bewley. 2013. Characterization of Kentucky dairy producer decision-making behavior. J. Dairy Sci. 96:47514758.

Rutten, C. J., W. Steeneveld, C. Inchaisri, and H. Hogeveen. 2014. An ex ante analysis on the use of activity meters for automated estrus detection: To invest or not to invest? J. Dairy Sci. 97:6869-6887.

Rutten, C. J., A. G. J. Velthuis, W. Steeneveld, and H. Hogeveen. 2013. Invited review: Sensors to support health management on dairy farms. J. Dairy Sci. 96:1928-1952.

Sauer, J., and D. Zilberman. 2012. Sequential technology implementation, network externalities, and risk: The case of automatic milking systems. Agric. Econ. 43:233-251.

Steeneveld, W., L. W. Tauer, H. Hogeveen, and A. Oude Lansink. 2012. Comparing technical efficiency of farms with an automatic milking system and a conventional milking system. J. Dairy Sci. 95:7391-7398.

van Asseldonk, M., A. W. Jalvingh, R. B. M. Huirne, and A. A. Dijkhuizen. 1999. Potential economic benefits from changes in management via information technology applications on Dutch dairy farms: A simulation study. Livest. Prod. Sci. 60:33-44.

van der Tol, R., and A. van der Kamp. 2010. Time series analysis of live weight as health indicator. Pages 230-231 in Proc. First North Am. Conf. Precision Dairy Management, Toronto, Canada.

Whyte, D. S., R. G. Orchard, P. S. Cross, T. Frietsch, R. W. Claycomb, G. A. Mein, A. Meijering, H. Hogeveen, and C. J. A. M. de Koning. 2004. An on-line somatic cell count sensor. Pages 235-240 in Automatic Milking: A better understanding. Wageningen Academic Publishers, Wageningen, the Netherlands. 